\title{
Human Platelet Fc Receptor for Immunoglobulin G Identification as a 40,000-Molecular-Weight Membrane Protein Shared by Monocytes
}

\author{
S. I. Rosenfeld, R. J. Looney, J. P. Leddy, D. C. Phipps, G. N. Abraham, and C. L. Anderson \\ Clinical Immunology, Allergy, and Rheumatology Unit, Department of Medicine, University of Rochester School of Medicine and \\ Dentistry, Rochester, New York 14642
}

\section{Abstract}

We have recently shown that human monocytes and $\mathrm{U} 937$ cells possess two molecular classes of $\mathrm{Fc} \gamma$ receptor. One, a 72,000mol-wt sialoglycoprotein, has high affinity for certain subclasses of human and murine monomeric IgG. The other is a $40,000-$ mol-wt protein (p40) with low affinity for monomeric IgG but with the capacity to bind IgG aggregates or IgG-coated particles.

In the present study, a 40,000-mol-wt single chain protein, apparently identical to $\mathbf{p 4 0}$ from $\mathbf{U} 937$ cells, was isolated from surface-radioiodinated human platelets by affinity purification using a murine IgG2b monoclonal antibody to $\mathbf{p 4 0}$. This $\mathbf{4 0 , 0 0 0 -}$ mol-wt protein was not seen when control IgG2b or unrelated murine monoclonal antibodies were employed in place of antip40. The same 40,000-mol-wt protein was also recovered from an IgG-Sepharose affinity adsorbent, but not from ovalbuminor myoglobin-Sepharose. The 72,000-mol-wt Fc $\gamma$ receptor of monocytes was not identified on platelets.

Monoclonal anti-p40 and Fab fragments derived from this antibody blocked platelet aggregation by heat-aggregated human IgG, whereas a control murine IgG2b protein had little or no inhibitory effect at 500-1,000-fold higher concentrations. A murine IgG1 monoclonal antibody, reactive with an unrelated platelet-specific membrane antigen, did not inhibit platelet responses to aggregated IgG. Anti-p40 did not affect platelet aggregation by thrombin, collagen, or fibrinogen plus ADP. Although antip40 did not directly aggregate platelets in the concentrations employed, cross-linking with $\mathrm{F}\left(\mathrm{ab}^{\prime}\right)_{2}$ goat anti-murine Ig induced apyrase-sensitive aggregation of anti-p40-treated platelets. This indicates that $\mathbf{4 0}$ possesses transmembrane linkage for platelet activation and secretion.

These observations strongly suggest that this newly recognized 40,000-mol-wt platelet membrane protein serves as an $\mathrm{Fc \gamma}$ receptor.

\section{Introduction}

The existence of $\mathrm{Fc} \gamma$ receptors on human platelets has been supported by several lines of evidence, including Fc-dependent secretory and aggregation responses to IgG aggregates and IgGbearing immune complexes (1-6), direct radioligand binding studies with IgG dimers and larger oligomers (7), and a report

Address correspondence to Dr. Rosenfeld, Box 695, University of Rochester Medical Center, Rochester, NY 14642.

Received for publication 24 June 1985.

J. Clin. Invest.

(C) The American Society for Clinical Investigation, Inc.

$0021-9738 / 85 / 12 / 2317 / 06 \quad \$ 1.00$

Volume 76, December 1985, 2317-2322 of a $\mathrm{KBr}$-solubilized 255,000 -mol-wt platelet membrane glycoprotein exhibiting reactivity with aggregated $\operatorname{IgG}(8)$.

In recent reports from this laboratory $(9,10)$ evidence was presented that human monocytes and a related cell line, U937, possess two molecular classes of $\mathrm{Fc} \gamma$ receptors: one, the high affinity 72,000 -mol-wt sialoglycoprotein receptor $(\mathrm{p} 72)^{1}$ previously described (11); the other, a newly recognized 40,000-molwt membrane protein ( $\mathrm{p} 40)$. Molecular and functional analysis of the $\mathrm{p} 40$ protein was facilitated by the development of a murine anti-p40 monoclonal antibody (MAb). This MAb also recognizes p40 molecules on human granulocytes, on the erythroblastic cell line, K562, and, more weakly, on the B lymphocyte line, Daudi (9).

In the present study on human platelets, application of this anti-p40 MAb as well as IgG affinity adsorption procedures have demonstrated that the platelet possesses a 40,000-mol-wt membrane protein that is very similar, if not identical, to $\mathrm{p} 40$ derived from U937 cells. Functional studies suggest that this 40,000mol-wt protein serves as a platelet $\mathrm{Fc} \gamma$ receptor.

\section{Methods}

Buffers. Phosphate-buffered saline (PBS), pH 7.0, contained $146 \mathrm{mM}$ $\mathrm{NaCl}$ and $20 \mathrm{mM}$ phosphate. Standard Tyrode's buffer, $\mathrm{pH}$ 7.3, contained $138 \mathrm{mM} \mathrm{NaCl}, 2.7 \mathrm{mM} \mathrm{KCl}, 12 \mathrm{mM} \mathrm{NaHCO}{ }_{3}, 0.36 \mathrm{mM} \mathrm{NaH}_{2} \mathrm{PO}_{4}, 1$ $\mathrm{mM} \mathrm{MgCl}$, and $5.5 \mathrm{mM}$ dextrose. Several modified Tyrode's buffers, all at $\mathrm{pH} 7.3$, were employed as follows: $(a)$ with 6.6 mM EDTA; $(b)$ with $6.6 \mathrm{mM}$ EDTA plus $2 \%$ bovine serum albumin (BSA) (Sigma Chemical Co., St. Louis, MO); (c) with $6.6 \mathrm{mM}$ EDTA plus $5 \mathrm{mM} \mathrm{KI}$; and $(d)$ with $2 \mathrm{mM} \mathrm{CaCl}_{2}$ plus $2 \%$ BSA.

Platelet-reactive reagents. Human IgG was purified from Cohn fraction II (Sigma Chemical Co.) by DEAE-cellulose chromatography. Aggregated IgG was prepared from a stock solution of this IgG $(10 \mathrm{mg} / \mathrm{ml}$ in PBS) on the day of each experiment by heating $\left(63^{\circ} \mathrm{C}, 15-30 \mathrm{~min}\right)$ after which insoluble material was removed by centrifugation. Human thrombin $\alpha$-Ila was a gift from Dr. Paula Tracy and Dr. William Rodgers, Department of Pathology, University of Rochester Medical Center, Rochester, NY. Collagen (calf skin), adenosine 5'-diphosphate, and apyrase were all purchased from Sigma Chemical Co. Fibrinogen, purified from human plasma by the method of Blomback and Blomback (12), and $99 \%$ clottable by thrombin, was lyophilized in $68 \mathrm{mM}$ Na citrate$78 \mathrm{mM} \mathrm{NaCl}$, stored at $4^{\circ} \mathrm{C}$, and freshly reconstituted in distilled water for each experiment.

Murine antibodies and immunoglobulins. Preparation of monoclonal IgG2b anti-p40 (IV.3) is fully described elsewhere (9). Briefly, CAF1 $[(\mathrm{BALB} / \mathrm{c} \times \mathrm{A} / \mathrm{J}) \mathrm{F} 1]$ mice were immunized with p40-rich $\mathrm{K} 562$ human erythroid cells and hybridomas prepared by fusion of spleen cells with cells of the P3. $\times 63$. Ag8.653 nonsecretory cell line by methods described

1. Abbreviations used in this paper: DTT, dithiothreitol; MAb, monoclonal antibody; MOPC, mineral oil-induced plasmacytoma; $\mathbf{4 0 \text { , a }}$ 40,000-mol-wt membrane protein; p72, a 72,000-mol-wt membrane protein; RT, room temperature; SDS-PAGE, sodium dodecyl sulfate polyacrylamide gel electrophoresis. 
previously $(13,14)$. Culture supernatants of clones were screened for their ability to inhibit rosette formation of K562 cells with human erythrocytes precoated with murine-IgG1 antiglycophorin antibody (gift of Dr. W. L. Bigbee, Lawrence Livermore National Laboratories, Livermore, CA). Anti-p40 employed in experiments on receptor isolation was supernatant culture fluid of clone IV. 3 in RPMI 1640 supplemented by $10 \%$ fetal bovine serum (HyClone Laboratories, Sterile Systems Inc., Logan, UT), penicillin ( $100 \mathrm{U} / \mathrm{ml})$, streptomycin $(100 \mu \mathrm{g} / \mathrm{ml})$, gentamycin $(40 \mu \mathrm{g} / \mathrm{ml})$, L-glutamine $(0.3 \mathrm{mM})$, Hepes $(1 \mathrm{mM})$, 2-mercaptoethanol $(50 \mu \mathrm{M})$, sodium pyruvate ( $2 \mathrm{mM})$, and Eagles's minimal essential medium nonessential amino acids $(50 \mu \mathrm{M})$ (Gibco, Grand Island, NY). Functional (inhibition) studies employed DE-52 (Whatman Inc., Clifton, $\mathrm{NJ})$ chromatographically isolated IgG from ascites of CAF1 mice that had been inoculated with hybridoma IV.3. Control antibodies and immunoglobulins were as follows: (a) UR-1, an IgG1 murine monoclonal antibody selectively reactive with the human platelet membrane (precise antigen specificity unknown) (15) kindly supplied as ascites fluid by Dr. Neil Blumberg, Department of Pathology, University of Rochester Medical Center ${ }^{2}$; (b) mineral oil-induced plasmacytoma (MOPC)-141 murine IgG2b myeloma protein purified from ascites by DE-52 anion exchange chromatography; and $(c)$ IgG2b murine monoclonal anti-Vkiiib, previously described (14).

After preliminary studies to establish correct conditions, papain digests of IgG2b anti-p40 (IV.3) and IgG2b MOPC-141 myeloma protein were concurrently prepared from DE-52 purified fractions of each protein by incubation $\left(37^{\circ} \mathrm{C}, 30 \mathrm{~min}\right)$ with a $1: 25$ enzyme/substrate ratio (wt/wt) of papain (Cooper Biomedical Inc., Malvern, PA) in PBS, pH 7.0, containing $10 \mathrm{mM}$ cysteine and $5 \mathrm{mM}$ EDTA. The reaction was stopped with $20 \mathrm{mM}$ iodoacetamide. The production of fragments having relative molecular weight consistent with $\mathrm{Fab}$ and $\mathrm{Fc}$ fragments and degradation of intact IgG molecules was verified by Coomassie Blue staining of sodium dodecyl sulfate-polyacrylamide gel electrophoresis (SDS-PAGE) slabs (16), using $10 \%$ acrylamide for unreduced proteins and $12.5 \%$ for reduced proteins. Although these gels showed no detectable intact IgG, the preparations were diluted to $1 \mathrm{mg} / \mathrm{ml}$ in PBS, dialyzed against RPMI 1640 , and incubated for $1 \mathrm{~h}$ at $4^{\circ} \mathrm{C}$ with Sepharose-Staphylococcus aureus protein $\mathrm{A}$ to remove $\mathrm{Fc}$ fragments as well as any last traces of intact IgG.

Protein-Sepharose adsorbents. Proteins were coupled to Sepharose 4B (Pharmacia Fine Chemicals, Div. of Pharmacia Inc., Piscataway, NJ) by the cyanogen bromide procedure to yield the following adsorbents: Sepharose-human IgG $(7.59 \mathrm{mg} / \mathrm{ml}$ Sepharose beads), Sepharose-myoglobin $(2.1 \mathrm{mg} / \mathrm{ml})$, Sepharose-ovalbumin $(1.75 \mathrm{mg} / \mathrm{ml})$, and Sepharose goat $\mathrm{F}\left(\mathrm{ab}^{\prime}\right)_{2}$ anti-murine $\mathrm{Ig}(1 \mathrm{mg} / \mathrm{ml})$. $S$. aureus protein A-Sepharose CL-4B was purchased from Pharmacia Fine Chemicals. Human IgG was prepared as described above. Sperm whale myoglobin and ovalbumin were purchased from Sigma Chemical Co. Goat $\mathrm{F}\left(\mathrm{ab}^{\prime}\right)_{2}$ anti-murine Ig (reactive with IgG, IgA, IgM, heavy and light chains) was purchased from Cappel Laboratories Inc., Malvern, PA. The latter $\mathrm{F}\left(\mathrm{ab}^{\prime}\right)_{2}$ antibody, in soluble form, was also used as a second antibody in receptor-bridging studies (see below).

Platelets and U937 cells. Washed platelets were prepared by a modification (17) of a published method (18) from blood freshly collected by gravity into citrate anticoagulant from male donors who had not taken aspirin or related antirheumatic drugs for $2 \mathrm{wk}$, or ethanol for 24 h. The platelets were washed twice in Tyrode's buffer, $\mathrm{pH} 7.3$, containing $6.6 \mathrm{mM}$ EDTA and 2\% BSA, and twice more in Tyrode's/EDTA, followed by surface radiolabeling (see below). Platelets used for functional assays were washed the same way, except that all four washes with Tyrode's/ EDTA contained 2\% BSA. Since the platelet aggregation responses tested here require extracellular calcium, the washed platelets in Tyrode's/ EDTA/BSA were spun and resuspended in Tyrode's buffer, pH 7.3, con-

2. Preliminary experiments indicate that this antibody precipitates two surface proteins from human platelets. Their approximate molecular weights are $125,000-135,000$ and $110,000-120,000$ (reduced), and 140,000-145,000 and 90,000-100,000 (unreduced) (D. C. Phipps, S. I. Rosenfeld, and J. P. Leddy, unpublished observations). taining $2 \mathrm{mM} \mathrm{CaCl}$ and $2 \%$ BSA. The platelets were counted electronically, adjusted to $300,000 / \mathrm{mm}^{3}$ in the same buffer, and held at room temperature (RT) until tested. For platelets involved in $\mathrm{Fc} \gamma$ receptor solubilization, the purity of the platelet preparation was assessed. Electronic counting of washed platelets $\left(4.47 \times 10^{5} / \mathrm{mm}^{3}\right)$ revealed leukocyte contamination of $\sim 600 / \mathrm{mm}^{3}(0.134 \%$ of the platelet count) and erythrocyte contamination at $1 \times 10^{4} / \mathrm{mm}^{3}$. Microscopic examination of Wright's stained cytocentrifuge smears demonstrated that the great majority of contaminating leukocytes were lymphocytes, e.g., in the preparation used in Fig. 1, there were $73 \%$ lymphocytes, $25 \%$ monocytes, and $2 \%$ neutrophils. Independent analysis by flow microfluorimetry has revealed no demonstrable binding of anti-p40 to normal peripheral blood lymphocytes (Looney, R. J., D. H. Ryan, and C. L. Anderson, unpublished observations). U937 cells were grown and prepared for radiolabeling as previously described (19).

Surface-radioiodination of platelets and U937 cells. Washed platelets $\left(2 \times 10^{9}\right)$ in $0.7 \mathrm{ml}$ Tyrode's buffer containing $6.6 \mathrm{mM}$ EDTA were added to a flat-bottomed glass vial precoated with $5 \mu \mathrm{g}$ chloroglycouril (Pierce Chemical Co., Rockford, IL) followed by $1 \mathrm{mCi}$ carrier-free $\mathrm{Na}^{125} \mathrm{I}$ (Amersham Corp., Arlington Heights, IL). After a 30-min incubation at room temperature, the reaction was quenched by addition of $5 \mathrm{mM} \mathrm{KI}$ in Tyrode's/EDTA. The platelets were immediately transferred to a clean tube, washed twice in the same buffer, transferred to a second tube, and washed one more time in Tyrode's/EDTA/KI. U937 cells $\left(1 \times 10^{7}\right)$ were radiolabeled in similar fashion $(11,19)$.

Pelleted labeled platelets or U937 cells were solubilized in $2.0 \mathrm{ml}$ or $0.2 \mathrm{ml}$, respectively, of a pH 7.1-buffer mixture containing $1 \% \mathrm{NP}-40$, $20 \mathrm{mM}$ Tris, $110 \mathrm{mM} \mathrm{NaCl}, 10 \mathrm{mM}$ EDTA, $5 \mathrm{mM} \mathrm{KI}, 10 \mu \mathrm{g} / \mathrm{ml}$ pepstatin, $10 \mu \mathrm{g} / \mathrm{ml}$ chymostatin, $10 \mu \mathrm{g} / \mathrm{ml}$ leupeptin, $10 \mu \mathrm{g} / \mathrm{ml}$ antipain, and $1 \mathrm{mM}$ phenylmethyl sulfonylfluoride (all inhibitors from Sigma Chemical Co.). After a 30-min incubation on ice, the lysates were subjected to centrifugation at $12,000 \mathrm{~g}$ for $20 \mathrm{~min}$ at $4^{\circ} \mathrm{C}$. Supernatants were recovered and held on ice. The percentage of radioactivity precipitable by $12.5 \%$ TCA was determined: platelets, $25-42 \%$ (seven experiments); U937 cells, 4.8-5.4\% (two experiments).

Receptor isolation using monoclonal anti-p40. $100 \mu \mathrm{l}$ lysate was incubated ( $1 \mathrm{~h}$ on ice) with $50 \mu \mathrm{l}$ undiluted anti-p40 (IV.3) in culture supernatant (see above) or with control murine antibodies or immunoglobulins. The mixtures were transferred to $1.5-\mathrm{ml}$ microcentrifuge tubes containing $25 \mu \mathrm{l}$ packed Sepharose-goat $\mathrm{F}\left(\mathrm{ab}^{\prime}\right)_{2}$ anti-murine Ig that had been washed twice with $1 \mathrm{ml} 1 \% \mathrm{NP}-40 / 5 \mathrm{mM} \mathrm{KI}$ in PBS. After incubation for $1 \mathrm{~h}$ on ice with mixing at 10-min intervals, the Sepharose was washed five times in PBS containing 0.5\% NP-40, 0.1\% SDS, $5 \mathrm{mM}$ $\mathrm{KI}$, and $0.02 \% \mathrm{NaN}_{3}$. The contents were transferred to fresh tubes and washed one more time in the same buffer mixture. The Sepharose pellets were suspended in $80 \mu$ l Laemmli's (16) sample buffer containing $2 \%$ SDS with or without $20 \mathrm{mM}$ dithiothreitol (DTT) (Pierce Chemical Co.), in place of 2-mercaptoethanol, followed by mixing and boiling for 2 min. Addition of $5 \mu \mathrm{l} 1 \mathrm{M}$ iodoacetamide (Sigma Chemical Co.) was followed by microcentrifugation (Beckman Instruments Inc., Spinco Div., Palo Alto, CA) for $30 \mathrm{~s}$. The supernatants were removed and applied to a $5-15 \%$ polyacrylamide gradient slab gel in $0.1 \%$ SDS. The gels were stained with Coomassie Blue, dried on filter paper, and then analyzed by autoradiography using XAR-2 film (Eastman Kodak Co., Rochester, NY). Unlabeled high and low molecular weight markers (Bio-Rad Laboratories, Richmond, CA) included myosin $(200,000), \beta$-galactosidase $(130,000)$, phosphorylase B $(94,000)$, BSA $(68,000)$, ovalbumin $(43,000)$, carbonic anhydrase $(30,000)$, soybean trypsin inhibitor $(21,000)$, and lysozyme $(14,300)$. Radiolabeled BSA was included for alignment of the autoradiographs.

Receptor isolation using Sepharose-IgG. Sepharose-IgG and other (control) Sepharose conjugates were washed sequentially with PBS containing $1 \mathrm{mg} / \mathrm{ml}$ BSA, PBS alone, $0.5 \mathrm{M}$ acetic acid, PBS alone (twice), and twice with PBS containing $1 \% \mathrm{NP}-40$ and $5 \mathrm{mM}$ KI. Packed Sepharose-IgG (or control Sepharose), $25 \mu$, was incubated at $2-4^{\circ} \mathrm{C}$ with $100 \mu \mathrm{l}$ radiolabeled lysate with mixing. Incubation times varied from 1 $h$ to overnight. Both shorter and longer incubation times yielded the $p 40$ protein from Sepharose-IgG, but nonspecific protein bands (eluted from 
both Sepharose-IgG and control Sepharose conjugates) were more pronounced when overnight incubation was employed. After incubation the adsorbents were washed five times with PBS containing $1 \%$ NP-40 and $5 \mathrm{mM} \mathrm{KI}$, transferred to fresh tubes, and washed a sixth time. Elution of bound proteins and SDS-PAGE autoradiography were the same as for the monoclonal antibody procedure.

Platelet aggregometry. Freshly isolated washed platelets, $450 \mu \mathrm{l}$, at $300,000 / \mathrm{mm}^{3}$, were mixed in aggregometer cuvettes, with $10 \mu \mathrm{l}$ of varying dilutions (in Tyrode's/Ca ${ }^{++} / \mathrm{BSA}$ ) of anti-p40 (IV.3) or with control antibodies or murine IgG2b, and incubated at RT for $10 \mathrm{~min}$. The cuvettes were then placed in a dual channel recording aggregometer (ChronoLog, Havertown, PA) at $37^{\circ} \mathrm{C}$ with stirring. After $1 \mathrm{~min}$, platelet aggregating agents, in $50 \mu \mathrm{l}$ vol, were added. These included heat-aggregated human IgG $(5 \mathrm{mg} / \mathrm{ml})$, collagen $(\sim 0.5 \mathrm{mg} / \mathrm{ml})$, thrombin $(\sim 0.2 \mathrm{U} / \mathrm{ml})$, or ADP $(50 \mu \mathrm{M})$ plus fibrinogen $(8 \mathrm{mg} / \mathrm{ml})$ (all initial concentrations). Negative responses were followed for $15 \mathrm{~min}$. Results were recorded as: (a) the maximal slope of the change in light transmission per unit time (expressed as the fraction of the maximum possible deflection per 0.2min interval); (b) the time to onset of aggregation after addition of the stimulus; and $(c)$ the amplitude of the upstroke of the aggregometer curve estimated graphically. We have found that the slope is the single best quantitative correlate of these responses, although the amplitude measurement (percent aggregation) gives similar results.

Anti-p40 itself did not induce platelet aggregation, at least over the dose range employed. Bridging experiments with a second antibody were carried out by a modification of the above procedure. After $10 \mu$ l diluted anti-p40 (IV.3) had been incubated (RT, $10 \mathrm{~min}$ ) with $450 \mu \mathrm{l}$ washed platelets, $50 \mu \mathrm{l} \mathrm{F}\left(\mathrm{ab}^{\prime}\right)_{2}$ goat anti-mouse $\mathrm{Ig}(60 \mu \mathrm{g} / \mathrm{ml})$ were added at $37^{\circ} \mathrm{C}$, and the mixture was observed for platelet aggregation in parallel with appropriate control mixtures (see below). In such experiments positive results were followed by repeat application of the same antibody concentrations in the presence of apyrase $(64 \mu \mathrm{g} / \mathrm{ml})$ in order to distinguish ADP-dependent platelet aggregation from agglutination of platelets.

\section{Results}

Detergent-solubilized platelets were sequentially exposed to the murine IgG2b MAb anti-p40 (IV.3) and solid phase $\mathrm{F}\left(\mathrm{ab}^{\prime}\right)_{2}$ goat anti-mouse Ig, and the complexes were eluted by $2 \%$ SDS in the presence or absence of $20 \mathrm{mM}$ DTT. Analysis of the eluates by autoradiography of SDS-PAGE slab gels consistently revealed a protein of $M_{\mathrm{r}} 40,000$ in similar position to that of $\mathrm{p} 40$ extracted from concurrently studied U937 cells (Fig. 1, left, lanes $C$, and $D$, and $G$, and $H$ ). Neither platelet p40 nor U937-p40 appeared to be derived from a higher molecular weight multichain protein since reduction had only a slight effect on apparent molecular weight. Other bands faintly visible in the specific anti-p40 track are also seen in the tracks of eluates derived by exposure to control murine IgG2b (MOPC-141) prior to the solid phase goat $\mathrm{F}\left(\mathrm{ab}^{\prime}\right)_{2}$ anti-murine Ig (Fig. 1, left, lanes $A$, and $B$, and $E$, and $F)$. The p40 band, however, was not recovered when either MOPC-141 (Fig. 1) or IgG2b murine MAb anti-Vkiiib (not shown) was used in place of anti-p40 (IV.3).

The platelet preparation used for this experiment contained a small number of monocytes $(0.034 \%$ of the platelet count). Since monocytes contain about the same amount of anti-p40 as do U937 cells, (Looney, R. J., and C. L. Anderson, unpublished observations) the contaminating monocytes could contribute to lanes $C$ and $D$ (Fig. 1, left) no more than $0.7 \%$ of the p40 seen in lanes $G$ and $H$ (Fig. 1, left), clearly much less than the amount actually found in lanes $C$ and $D$.

Extraction of detergent-solubilized, surface-labeled platelets by an alternative method based on affinity for IgG-Sepharose (Methods) also yielded p40 in eluates from surface-labeled

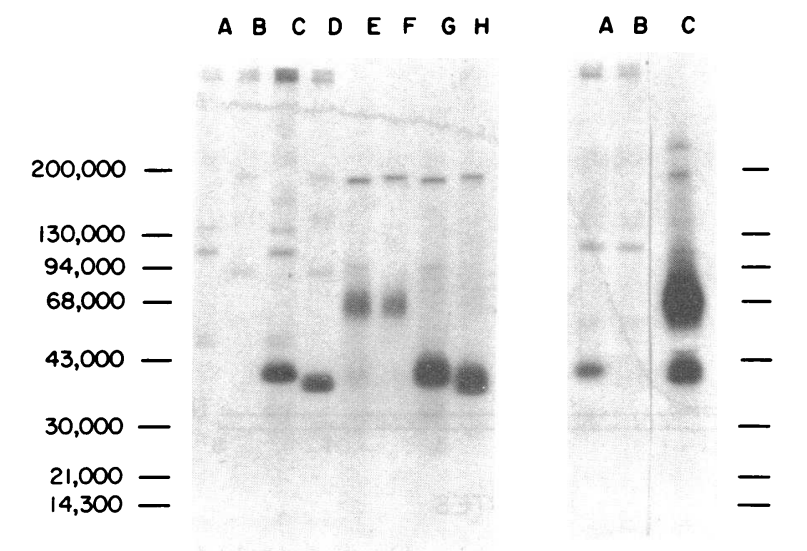

Figure 1. Autoradiographs of SDS-PAGE 5-15\% gradient slab gels. (left) Immunoprecipitation from detergent lysates of surface-radiolabeled cells by murine monoclonal antibody or control immunoglobulin followed by Sepharose goat $\mathrm{F}\left(\mathrm{ab}^{\prime}\right)_{2}$ anti-murine Ig: lane $A$, platelet lysate + MOPC-141 + $20 \mathrm{mM}$ DTT; lane $B$, same, without DTT; lane $C$, platelet lysate + anti-p40 (IV.3) +20 mM DTT; lane $D$, same, without DTT; lane $E$, U937 lysate + MOPC-141 + 20 mM DTT; lane $F$, same, without DTT; lane $G$, U937 lysate + anti-p40 (IV.3) $+20 \mathrm{mM}$ DTT; lane $H$, same without DTT. (right) Eluates from affinity adsorbents as follows: lane $A$, platelet lysates applied to Sepharose-IgG; lane $B$, platelet lysates applied to Sepharose-myoglobin; lane $C$, U937 lysates applied to Sepharose-IgG. All eluates contain $20 \mathrm{mM}$ DTT.

platelets (Fig. 1, right, lane $A$ ). The additional bands, mostly of higher molecular weight, seen in the autoradiograph were also found in eluates derived from the nonspecific adsorbents, Sepharose-myoglobin (Fig. 1, right, lane B) or Sepharose-ovalbumin (not shown). However, p40 was not recovered from the latter adsorbents. The $\mathrm{p} 72$ glycoprotein, which had previously been identified in U937 cells and normal human monocytes and was associated with high affinity binding of monomeric IgG $(11,19,20)$, was not recovered from platelet lysates exposed to Sepharose-IgG (Fig. 1, right, lane $A$ ). As expected, U937 cells yielded both $\mathrm{p} 40$ and $\mathrm{p} 72$ bands under these same conditions (Fig. 1, right, lane $C$ ). The p40 band was identified with antip40 (IV.3) in platelets from three different donors and with IgGSepharose in two of these plus one other donor (total of four different donors tested).

To establish that this newly identified 40,000-mol-wt platelet membrane protein was associated with biological responses attributable to an $\mathrm{Fc} \gamma$ receptor, the following studies were performed. First, MAb anti-p40 (IV.3) and murine myeloma protein of the same IgG2b subclass (MOPC-141), both chromatographically purified from ascites fluid (Methods), were compared in dose-responsive fashion for their capacity to inhibit platelet aggregation by aggregated human IgG. Freshly prepared suspensions of washed platelets were preincubated $(10 \mathrm{~min}, \mathrm{RT})$ in aggregometer cuvettes with varying concentrations of anti-p40 or MOPC-141, after which the cuvettes were placed in the aggregometer at $37^{\circ} \mathrm{C}$ and aggregated IgG was added. Fig. 2 illustrates typical aggregometer tracings for single concentrations of anti-p40 and MOPC-141. Superimposed on the positive platelet aggregation tracing (curve $A$ ) are the dimensions $(y, x)$ used to calculate maximum slope (Methods). Table I summarizes the slopes for the full dose ranges over which IgG2b anti-p40 (IV.3) and MOPC-141 IgG2b were compared. Anti-p40 was able to 


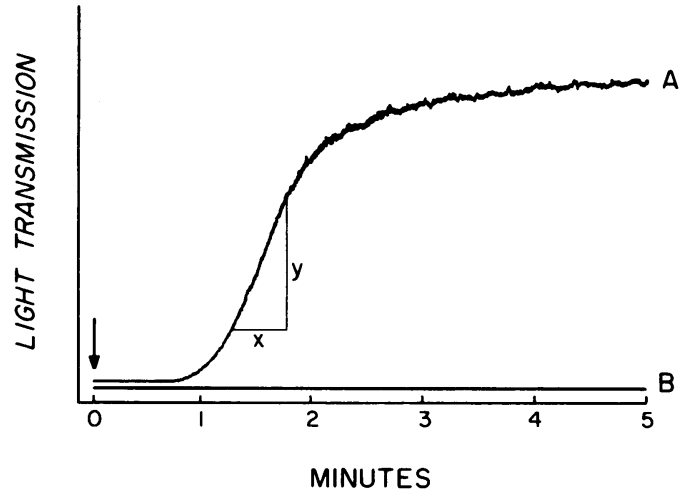

Figure 2. Platelet aggregation induced by aggregated IgG. $(A)$ Platelets preincubated ( $10 \mathrm{~min}, \mathrm{RT}$ ) with IgG2b MOPC-141 myeloma protein $(217 \mathrm{ng} / \mathrm{ml}) ;(B)$ Platelets preincubated $(10 \mathrm{~min}, \mathrm{RT})$ with $\mathrm{IgG} 2 \mathrm{~b}$ anti$\mathrm{p} 40(\mathrm{IV} .3)(85 \mathrm{ng} / \mathrm{ml})$. The arrow marks the addition of aggregated IgG. Parameters for graphic estimation of maximal slope $(y, x)$ are illustrated on $A$ (Methods).

completely block platelet aggregation down to a final concentration of $43 \mathrm{ng} / \mathrm{ml}$ and reproducibly induced partial inhibition at $17 \mathrm{ng} / \mathrm{ml}$. MOPC-141 produced little or no inhibition at concentrations up to 2,000 -fold higher $(43 \mu \mathrm{g} / \mathrm{ml})$. In the same experiments platelet aggregation by ADP plus fibrinogen, by thrombin or by collagen, was unaffected by intact anti-p40 at several concentrations that totally inhibited the responses to aggregated IgG (not shown).

Table I. Inhibition of Aggregated IgG-induced Platelet Aggregation by IgG2b Monoclonal Anti-p40 (IV.3) or Control IgG2b and their Fragments

\begin{tabular}{lll}
\hline Potential inhibitor & $\begin{array}{l}\text { Concentration during } \\
\text { preincubation with } \\
\text { platelets }\end{array}$ & $\begin{array}{l}\text { Platelet aggregation } \\
\text { by aggregated IgG }\end{array}$ \\
\hline & $\mu g / m l$ & max. slope* \\
None & - & $1.58-1.76 \ddagger$ \\
Intact MOPC-141 & 0.22 & 1.35 \\
& 2.17 & 1.49 \\
& 10.85 & 1.32 \\
& 21.74 & 1.12 \\
Intact anti-p40 (IV.3) & 43.48 & 0.88 \\
& 0.009 & 0.98 \\
& 0.017 & $0.35,0.41$ \\
& 0.043 & 0,0 \\
Papain digest, anti-p40 & 0.085 & 0 \\
& 0.022 & 1.76 \\
& 0.043 & 1.61 \\
& 0.22 & 0.41 \\
& 0.44 & 0 \\
Papain digest, MOPC-141 & 0.22 & 1.61 \\
& 21.74 & 1.172 \\
& & \\
& &
\end{tabular}

* Maximum slope: see Methods and Fig. 2 for explanation. Zero slope means no change in light transmission, i.e., a flat tracing. $\ddagger$ Range of four determinations during the experiment.
Anti-p40 Fab fragments also effectively inhibited platelet responses to aggregated IgG although the protein concentrations required were 10-12-fold higher than for intact anti-p40 (Table I). Protein concentrations for Fab preparations are calculated from the concentration of the original undigested preparation. Fab from MOPC-141 IgG2b was not significantly inhibitory at concentrations as high as $21.7 \mu \mathrm{g} / \mathrm{ml}$.

Inhibition of platelet responses to aggregated IgG by intact anti-p40 was obtained using platelets from four different donors; inhibition with Fab fragments was successful with each of two platelet donors.

As a control for the possibility that binding of antibody to platelets at sites unrelated to $\mathrm{Fc}$ receptors might nonspecifically depress platelet responsiveness to aggregated IgG, another murine (IgG1) monoclonal antibody, UR-1, was tested. This MAb has been found by flow cytometry to be selectively reactive with platelets among all cell types in human blood (15), but the membrane antigen that it recognizes has not yet been characterized. ${ }^{2}$ In initial dose-response studies, addition of undiluted UR-1 ascites fluid $(10 \mu \mathrm{l})$ to washed platelets $(450 \mu \mathrm{l})$ in the aggregometer induced a rapid increase in light transmission. Since this was only slightly affected by prior addition of apyrase, this reaction may represent agglutination rather than aggregation. In any event, a 1/4 dilution of UR-1 (tested in the same reaction volumes) produced no observable direct effect on platelets but was assumed to bind at a subagglutinating level. Subsequent addition of aggregated human IgG, however, produced prompt aggregation that was fully comparable with that of control platelets (not shown).

Mab anti-p40 did not directly induce platelet aggregation, at least in the concentrations employed. When washed platelets that had been pretreated $(10 \mathrm{~min}, \mathrm{RT})$ with anti-p40 $(43 \mathrm{ng} / \mathrm{ml}$ final concentration) were exposed to a second bridging antibody, i.e., goat $\mathrm{F}\left(\mathrm{ab}^{\prime}\right)_{2}$ anti-murine IgG, prompt apyrase-sensitive aggregation was observed (Fig. 3). Appropriate controls using MOPC-141 or UR-1 as the first "antibody" prior to the $F\left(a b^{\prime}\right)_{2}$ goat antibody, or addition of the $\mathrm{F}\left(\mathrm{ab}^{\prime}\right)_{2}$ goat antibody alone, yielded no observable aggregation. We have found that the minimum concentration of intact anti-p40 mediating full inhibition

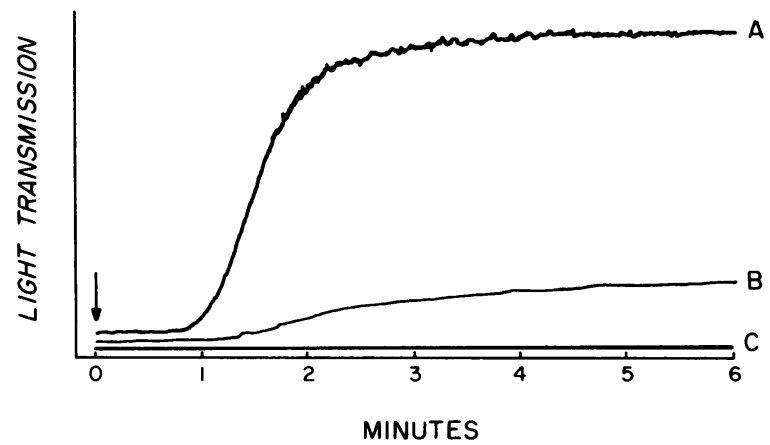

Figure 3. Receptor bridging experiment in which platelet aggregation is induced by monoclonal anti-p40 (IV.3) $(43 \mathrm{ng} / \mathrm{ml})$ followed by fluid-phase $\mathrm{F}\left(\mathrm{ab}^{\prime}\right)_{2}$ goat anti-murine $\mathrm{Ig}(6 \mu \mathrm{g} / \mathrm{ml})(A)$. $B$ represents the same reagents in the presence of apyrase $(64 \mu \mathrm{g} / \mathrm{ml})$. $C$ is representative of three concurrent controls: anti-p40 (IV.3) $(43 \mathrm{ng} / \mathrm{ml})$ alone, 1/10 UR-1 monoclonal anti-platelet antibody or MOPC-141 (43 ng/ $\mathrm{ml}$ ) followed by $\mathrm{F}\left(\mathrm{ab}^{\prime}\right)_{2}$ goat anti-murine Ig, and $\mathrm{F}\left(\mathrm{ab}^{\prime}\right)_{2}$ goat antibody alone. (All protein concentrations shown are final concentrations in the reaction mixtures.) The arrow marks the addition of the goat $\mathrm{F}\left(\mathrm{ab}^{\prime}\right)_{2}$ antibody. 
of platelet aggregation by aggregated IgG is very similar to the minimum concentration permitting platelet aggregation by receptor bridging via goat $\mathrm{F}\left(\mathrm{ab}^{\prime}\right)_{2}$ antibody. The fact that apyrase inhibited this reaction indicates that ADP was required. Therefore the platelet aggregation was an active process, requiring platelet secretion, as opposed to the passive, apyrase-insensitive agglutination produced by UR-1 (see above).

\section{Discussion}

Human platelets have been shown to possess a previously undescribed 40,000-mol-wt membrane protein for which the following evidence is consistent with its function as an $\mathrm{Fc} \gamma$ receptor. First, p40 is at least partially expressed on the cell surface, as demonstrated by consistent surface labeling. Second, it is immunoprecipitated from detergent lysates of platelets by MAb anti-p40 (IV.3) which had been shown to inhibit Fc $\gamma$ receptordependent rosette formation with IgG-coated erythrocytes by Fc $\gamma$-receptor-bearing histiocytic (U937) and erythroid (K562) human cell lines and by normal human monocytes, and to precipitate very similar, if not identical, surface-labeled membrane proteins from each of these cell types (9). Third, p40 is also recovered in eluates when detergent-lysed platelets are applied to the affinity adsorbent, IgG-Sepharose, but not in eluates from other protein-Sepharose conjugates. Fourth, and most importantly, MAb anti-p40 or its Fab fragments can completely but selectively block platelet aggregation induced by heat-aggregated human IgG under conditions wherein similar and 1000-fold greater concentrations of murine myeloma IgG or Fab of the same subclass (IgG2b) are ineffective, and an unrelated murine IgG1 anti-human platelet antibody fails to block this function. Fifth, although the tested concentrations of intact MAb antip40 did not induce platelet aggregation directly, addition of a second bridging antibody in the form of goat $\mathrm{F}\left(\mathrm{ab}^{\prime}\right)_{2}$ anti-mouse Ig did induce platelet aggregation, suggesting that the $\mathrm{p} 40$ protein possesses transmembrane linkage for cellular secretion and activation. The p72 class of $\mathrm{Fc} \gamma$ receptors demonstrated on U937 cells and human monocytes $(11,19)$ was not found on platelets.

Cheng and Hawiger (8) have described a 255,000-mol-wt multichain protein solubilized from unlabeled human platelets by a chaotropic agent $(2 \mathrm{M} \mathrm{KBr}$ ) without detergent and isolated by affinity chromatography on $\mathrm{Fc}(\mathrm{IgG})$-Sepharose. This protein yielded a single 50,000-mol-wt polypeptide chain upon reduction. Reactivity of the unreduced 255,000 -mol-wt protein with ${ }^{125} \mathrm{I}$-aggregated IgG was demonstrated in sucrose gradient ultracentrifugation. The relationship, if any, of this $255,000-\mathrm{mol}-w \mathrm{t}$ protein to our p40 is not evident. Although the 50,000-mol-wt polypeptide chain obtained by reduction is close in apparent molecular weight to $\mathrm{p} 40$, we found no evidence that $\mathrm{p} 40$ was derived from a higher molecular weight protein by disulfide reduction either in platelets or U937 cells. It is possible that human platelets possess more than one class of $\mathrm{Fc} \gamma$ receptor, as has emerged for mononuclear phagocytes of both human $(9,10)$ and mouse $(21,22)$. On the other hand, our anti-p40 MAb did totally block platelet responses to aggregated IgG. It is conceivable that p40 is the ligand recognition unit of a larger multiprotein complex that can maintain its multicomponent structure in the less stringent conditions of Cheng and Hawiger (8). This idea has precedent in the proposed multisubunit structure of the high affinity IgE receptors of rat mast cells and basophils $(23,24)$.

As a candidate for the platelet $\mathrm{Fc} \gamma$ receptor (or at least its ligand-binding unit), the currently known properties of $\mathrm{p} 40$ would be consistent with other observations. As an IgG-binding membrane protein in normal human monocytes $(9,10)$ and, more recently, in granulocytes (Looney, R. J., and C. L. Anderson, unpublished observations), p40 functions essentially as an IgG aggregate receptor, with very low affinity for monomeric IgG. Karas et al. (7) have reported that human platelets bind radiolabeled monomeric IgG very poorly and that only IgG dimers or small oligomers demonstrated stable binding. These findings, in turn, were in agreement with earlier observations of Ginsberg and Henson (25) that IgG aggregates of dimer to tetramer size are effective stimuli for human platelets. Indeed, in human platelets we have found no evidence for the p72 class of $\mathrm{Fc} \gamma$ receptors possessing high affinity $\left(\mathrm{Ka}=10^{8}-10^{9} \mathrm{M}^{-1}\right)$ for monomeric $\operatorname{IgG}(11,20)$.

Cellular activation by anti-receptor antibody has previously been observed in several systems (26-30). In these examples a single application of a polyclonal or monoclonal antibody was effective, whereas in our studies (Fig. 3) a second goat $F\left(a b^{\prime}\right)_{2}$ anti-murine Ig antibody was employed. Although we did not test high concentrations of monoclonal anti-p40 (IV.3) alone, because of limited supply, the concentrations tested were equal to those effecting total inhibition of platelet responses to aggregated IgG. We consider it more likely that the need for a second bridging antibody is related to questions of epitope density or accessibility on neighboring p40 molecules, or to the overall density of $\mathrm{p} 40$ proteins in platelet membranes.

It will be of interest in future studies with the anti-p40 MAb (or its Fab fragments) (a) to compare the (maximum) number of surface-expressed $\mathrm{p} 40$ molecules per platelet with the Fc $\gamma$ receptor estimates obtained by dimeric IgG binding (7), (b) to probe in greater detail the mechanism of platelet aggregation by Fc $\gamma$ receptor bridging, and (c) to explore the relationship, if any, of p40 to extensively studied major glycoproteins of the platelet membrane such as GP Ib $(31,32)$.

Note added in proof. MAb 3G8, which recognizes a 52-68,000-mol-wt $\mathrm{Fc} \gamma$ receptor on human neutrophils, was kindly provided by Dr. Howard Fleit, Department of Pathology, State University of New York, Stony Brook, NY. Using this MAb for immunoprecipitation of surface-labeled human platelet lysates, the $52-68,000$-mol-wt protein was not identified, which confirmed prior unpublished observations with immunofluorescence (H. Fleit and J. Unkeless, personal communication).

\section{Acknowledgments}

The authors thank Elsa Welch for technical assistance in the cultivation, harvesting, and ascites production involving hybridomas; Thomas $\mathbf{S}$. Edwards for assistance with U937 cell cultures and preparation of lysates; and Glynys R. Thomas for preparation of the manuscript.

This research was supported by U. S. Public Health Service research grants R01-AI2 1093, R01-AI19658, PO1-AI21288, and RO1-CA24067; by a James P. Wilmot Foundation Fellowship to Dr. Looney; and by the David Welk Memorial Fund.

\section{References}

1. Mueller-Eckhardt, C. L., and E. F. Lüscher. 1968. Immune reactions of human blood platelets. I. A comparative study on the effects on platelets of heterologous antiplatelet antiserum, antigen-antibody complexes, aggregated gammaglobulins, and thrombin. Thromb. Diath. Haemorrh. 20:155-167.

2. Pfueller, S. L., and E. F. Lüscher. 1972. The effects of aggregated immunoglobulins on human blood platelets in relation to their complement-fixing abilities. I. Studies of immunoglobulins of different types. J. Immunol. 109:517-525. 
3. Israels, E. D., G. Nisli, F. Paraskevas, and L. G. Israels. 1973. Platelet $\mathrm{Fc}$ receptor as a mechanism for $\mathrm{Ag}-\mathrm{Ab}$ complex-induced platelet injury. Thromb. Diath. Haemorrh. 29:434-444.

4. Henson, P. M., and H. L. Spiegelberg. 1973. Release of serotonin from human platelets induced by aggregated immunoglobulins of different classes and subclasses. J. Clin. Invest. 52:1282-1288.

5. Zimmerman, T. S., and H. L. Spiegelberg. 1975. Pneumococcusinduced release from human platelets. Identification of the participating plasma/serum factor as immunoglobulin. J. Clin. Invest. 56:828-834.

6. Henson, P. M., and M. H. Ginsberg. 1981. Immunological reactions of platelets. In Platelets in Biology and Pathology. J. L. Gordon, editor. Elsevier/North Holland Biomedical Press, Amsterdam. 265-308.

7. Karas, S. P., W. F. Rosse, and R. J. Kurlander. 1982. Characterization of the IgG-Fc receptor on human platelets. Blood. 60:1272-1282.

8. Cheng, C. M., and J. Hawiger. 1979. Affinity isolation and characterization of immunoglobulin $\mathrm{G} \mathrm{Fc} \mathrm{fragment-binding} \mathrm{glycoprotein} \mathrm{from}$ human blood platelets. J. Biol. Chem. 254:2165-2167.

9. Looney, R. J., G. N. Abraham, and C. L. Anderson. 1986. Human monocytes and U937 cells bear two distinct $F c$ receptors for $\operatorname{IgG}(\mathrm{Fc} \gamma \mathrm{R})$. J. Immunol. In press.

10. Jones, D. H., R. J. Looney, and C. L. Anderson. 1985. Two distinct classes of $\mathrm{IgG} \mathrm{Fc}$ receptors on a human monocyte line (U937) defined by differences in binding of murine IgG subclasses at low ionic strength. J. Immunol. 135:3348-3353.

11. Anderson, C. L. 1982. Isolation of the receptor for IgG from a human monocyte cell line (U937) and from peripheral blood monocytes. J. Exp. Med. 156:1794-1806.

12. Blomback, B., and M. Blomback. 1956. Purification of human and bovine fibrinogen. Ark. Kemi. 10:415-419.

13. Kohler, G., and C. Milstein. 1975. Continuous culture of fused cells secreting antibody of defined specificity. Nature (Lond.). 256:495497.

14. Greenstein, J. L., A. Solomon, and G. N. Abraham. 1984. Monoclonal antibodies reactive with idiotypic and variable region-specific determinants on human immunoglobulins. Immunology. 51:17-25.

15. Ryan, D., C. Ryan, L. Hennessy, N. Blumberg, P. Horan, E. Lord, M. Summers, and H. Cohen. 1982. Use of a monoclonal antiplatelet antibody in the clinical laboratory for platelet count estimation and detection of cytoplasmic fragmentation in the peripheral blood. Blood 60:204a. (Abstr.)

16. Laemmli, U. K. 1970. Cleavage of structural proteins during the assembly of the head of bacteriophage T4. Nature (Lond.). 227:680-685.

17. Breckenridge, R. T., S. I. Rosenfeld, K. S. Graff, and J. P. Leddy. 1977. Hereditary C5 deficiency in man. III. Studies of hemostasis and platelet responses to zymosan. J. Immunol. 118:12-16.

18. Zimmerman, T. S., and W. P. Kolb. 1976. Human platelet-ini- tiated formation and uptake of the C5-C9 complex of human complement. J. Clin. Invest. 57:203-211.

19. Anderson, C. L., J. M. Spence, T. S. Edwards, and J. Nusbacher. 1985. Characterization of a polyvalent antibody directed against the IgG Fc receptor of human mononuclear phagocytes. J. Immunol. 134:465470.

20. Anderson, C. L., and G. N. Abraham. 1980. Characterization of the $\mathrm{Fc}$ receptor for IgG on a human macrophage cell line, U937. $J$. Immunol. 125:2735-2741.

21. Heusser, C. H., C. L. Anderson, and H. M. Grey. 1977. Receptors for IgG: subclass specificity of receptors on different mouse cell types and the definition of two distinct receptors on a macrophage cell line. J. Exp. Med. 145:1316-1327.

22. Unkeless, J. C., H. Fleit, and I. S. Mellman. 1981. Structural aspects and heterogeneity of immunoglobulin Fc receptors. Adv. Immunol. 31:247-270.

23. Kulczycki, A., Jr. 1981. Role of immunoglobulin E and immunoglobulin E receptors in bronchial asthma. J. Allergy Clin. Immunol. 68:5-14.

24. Perez-Montfort, R., J-P. Kinet, and H. Metzger. 1983. A previously unrecognized subunit of the receptor for immunoglobulin E. Biochemistry. 22:5722-5728.

25. Ginsberg, M. H., and P. M. Henson. 1978. Enhancement of platelet response to immune complexes and IgG aggregates by lipid Arich bacterial lipopolysaccharides. J. Exp. Med. 147:207-218.

26. Ishizaka, T., and K. Ishizaka. 1978. Triggering of histamine release from rat mast cells by divalent antibodies against IgE receptors. J. Immunol. 120:800-805.

27. Isersky, C., J. Taurog, G. Poy, and H. Metzger. 1978. Triggering of cultured neoplastic mast cells by antibodies to the receptor for IgE. J. Immunol. 121:549-558.

28. Schechter, Y., L. Hernandez, J. Schlessinger, and P. Cuatrecasas. 1979. Local aggregation of hormone-receptor complexes is required for activation by epidermal growth factor. Nature (Lond.). 278:835-838.

29. Kahn, C. R., K. L. Baird, D. B. Jarrett, and J. S. Flier. 1978. Direct demonstration that receptor crosslinking or aggregation is important in insulin action. Proc. Natl. Acad. Sci. USA. 75:4209-4213.

30. Young, J. D.-E., J. C. Unkeless, H. R. Kaback, and Z. A. Cohn. 1983. Macrophage membrane potential changes associated with $\gamma 2 \mathrm{~b} /$ $\gamma 1$ Fc receptor-ligand binding. Proc. Natl. Acad. Sci. USA. 80:13561361.

31. Moore, A., G. D. Ross, and R. L. Nachman. 1978. Interaction of platelet membrane receptors with von Willebrand factor, ristocetin, and the Fc region of immunoglobulin G. J. Clin. Invest. 62:1053-1060.

32. Kunicki, T. J., N. Russell, A. T. Nurden, R. H. Aster, and J. P. Caen. 1981. Further studies of the human platelet receptor for quinineand quinidine-dependent antibodies. J. Immunol. 126:398-402. 